\title{
Penerapan Teknologi Image Processing untuk Optimalisasi Petik Merah pada Kebun Kopi Rakyat.
}

\author{
Aris Budianto ${ }^{1}$, Cucuk Budiyanto ${ }^{2}$, Qois Amin Fauzan ${ }^{3}$, \\ Indah Widiastuti $^{4}$, Dwi Maryono ${ }^{5}$ \\ ${ }^{1}$ Informatics Education Department, The Faculty of Teacher Training and Education Sebelas \\ Maret University Indonesia, ${ }^{2}$ Mechanical Engineering Education Dept., The Faculty of Teacher \\ Training and Education Sebelas Maret University Indonesia \\ Corresponding email: arisbudianto@staff.uns.ac.id
}

\begin{abstract}
Coffee has been cultivated as the secondary produce for decades in Girimarto, Wonogiri, however, the selective picking practice remain alient for local farmers. Selective picking is considered impractical due to time consumption and laborous work that farmers should carry out. The community service project designs and implements image recognition technology to help acquire coffee-cheery ripeness condition. Adopting a geolocation, the appropriate routing strategies, would enable farmers to selectively pick the red cherries in a systematic sequence. The image processing technology was applied by adopting Raspberry Pi microcomputer, Raspberry Pi Camera Board, version 2, and OpenCV programming language. The transition to selective picking and the subsequent post-harvest technology would likely produce high-quality green bean coffee. It is expected that the income of smallholder coffee farmers will gradually be increasing.
\end{abstract}

Keywords: IP camera; micro-computer; image processing; OpenCV programming; selective picking; smallholder coffee farm.

\begin{abstract}
ABSTRAK
Praktek petik buah merah dalam budidaya kopi belum menjadi prosedur baku pada perkebunan kopi rakyat di wilayah Girimarto, Wonogiri. Petani menganggap praktek petik merah pada panen buah kopi merepotkan dan memakan waktu karena dalam satu kunjungan ke kebun mereka hanya memetik buah kopi yang benar-benar matang. Pengabdian ini mendesain dan menerapkan perangkat pemantau kematangan buah kopi untuk membantu petani memperoleh informasi lokasi buah matang dan estimasi jumlahnya sehingga petani bisa merencanakan jalur pemetikan kopi berdasarkan lokasi batang pohon kopi tingkat kematangannya. Teknologi image processing diterapkan dengan mengadopsi penggunaan komputer mikro Raspberry Pi, modul kamera Raspberry Pi Camera Board, versi 2, dan bahasa pemrograman OpenCV. Perubahan pola panen buah kopi dari petik sembarang (petik racutan_ menjadi panen petik merah diikuti
\end{abstract}


dengan perbaikan proses fermentasi buah kopi diharapkan menghasilkan kualitas green bean menjadi lebih baik dan harga jual yang lebih tinggi.

Kata kunci: budidaya kopi rakyat; Modul kamera Raspberry Pi Camera Board, versi 2; mikro komputer; openCV; pengolahan citra; petik merah kopi.

\section{PENDAHULUAN}

Praktek petik buah merah dalam budidaya kopi belum menjadi prosedur baku pada perkebunan kopi rakyat di wilayah Girimarto, Wonogiri. Petani menganggap praktek petik merah pada panen buah kopi merepotkan dan memakan waktu karena dalam satu kunjungan ke kebun mereka hanya memetik buah kopi yang benar-benar matang. Lokasi kebun yang menyulitkan mobilitas dan luasan kebun menjadi faktor keengganan petani untuk

Dalam penelitian ini dilakukan deteksi kematangan buah kopi dengan menggunakan teknik segmentasi warna. Alasan dari pemilihan metode ini adalah buah kopi memiliki karakteristik buah kecil dan menggerombol. Sehingga metode yang tepat adalah mendeteksi area dengan warna tertentu.

Penelitian mengenai deteksi kematangan buah sudah banyak dilakukan dalam berbagai penelitian. Dalam penelitian ini akan mendeteksi kopi matang. Penelitian ini akan mendeteksi area yang mengandung kopi yang telah matang atau berwarna merah.

\section{TINJAUAN PUSTAKA}

\section{Standar Internasional Kualitas Biji Kopi}

Menghasilkan biji kopi yang berkualitas merupakan rangkaian proses panjang yang dimulai sejak pemilihan bibit tanaman kopi hingga proses roasting green bean kopi. Mengenai kualitas green bean, International Coffee Organization (ICO) telah merangkum standar dari berbagai negara yang telah mengirimkan dokumen ke ICO dan berkomitmen menjadi standar tersebut sebagai rujukan kualitas ekspor biji kopi dari masing-masing negara (ICO, 2019). Secara umum, terdapat 7 (tujuh) kriteria yang bisa digunakan untuk mengukur kualitas biji kopi untuk keperluan ekspor. Lima dari tujuh kriteria tersebut adalah ketinggian lokasi dan wilayah penanaman (altitude and region), jenis tanaman kopi (botanical type), pengolahan biji kopi (preparation), tampilan setelah disangrai dan kualitas cupping (roast appearrance and cup quality), dan kepadatan biji kopi (bean density) merupakan standar yang ditentukan untuk kopi khusus (specialty coffee). Sedangkan dua standar ukuran biji kopi (bean size) dan jumlah kerusakan biji kopi (bean defects) merupakan standar yang lebih banyak dipakai untuk perdagangan kopi secara umum.

Berdasarkan dokumen dari IOC tersebut, standar biji kopi Indonesia disusun dalamStandar Nasional Indonesia (SNI) dengan memperhitungkan jumlah biji rusak (bean defects) dalam setiap 250 biji kopi. Kategori kualitas biji kopi disajikan dalam Tabel 1 berikut ini sebagaimana disarikan dari SNI \# 01-2907-2008.

Tabel 1. Denominasi kualitas biji kopi dalam SNI

Kategori Deskripsi




\begin{tabular}{ll}
\hline Kualitas 1 & Jumlah biji rusak maksimum 11 \\
Kualitas 2 & Jumlah biji rusak antara 12 hingga 25 \\
Kualitas 3 & Jumlah biji rusak antara 26 hingga 44 \\
Kualitas 4a & Jumlah biji rusak antara 45 hingga 60 \\
Kualitas 4b & Jumlah biji rusak antara 61 hingga 80 \\
Kualitas 5 & Jumlah biji rusak antara 81 hingga 150 \\
Kualitas 6 & Jumlah biji rusak antara 151 hingga 225 \\
\hline
\end{tabular}

Tabel 2 berikut ini menyajikan jenis-jenis kerusakan biji kopi dan penyebab kerusakan tersebut. Terlihat bahwa kerusakan yang disebabkan oleh kesalahan dalam proses panen maupun kesalahan perlakuan paska panen menjadi penyebab paling besar kerusakan biji kopi. Kerusakan tersebut berakibat pada rendahnya harga jual biji kopi dari petani.

\begin{tabular}{|c|c|c|c|}
\hline \multicolumn{4}{|c|}{ Tabel 2. Daftar Kerusakan Biji Kopi dan Penyebabnya } \\
\hline No & Jenis kerusakan biji kopi. & Penyebab kerusakan biji kopi & Kategori \\
\hline 1 & $\begin{array}{l}\text { Biji menghitam } \\
\text { seluruhnya atau sebagian }\end{array}$ & Buah terlalu matang atau telanjur kering & Proses panen \\
\hline 2 & $\begin{array}{l}\text { Biji pecah dan kotor } \\
\text { serupa karat }\end{array}$ & $\begin{array}{l}\text { Buah dipanen belum matang; Biji pecah } \\
\text { saat dikupas dalam proses basah. }\end{array}$ & Proses panen \\
\hline 3 & Biji belum cukup matang & Buah dipetik sebelum matang / merah. & Proses panen \\
\hline 4 & Sour atau Sour sebagian & $\begin{array}{l}\text { Buah tidak segera dikupas setelah } \\
\text { dipetik; Fermentasi terlalu lama; Biji } \\
\text { yang masih lembab disimpan. }\end{array}$ & Paska panen \\
\hline 5 & Biji mengkristal & $\begin{array}{l}\text { Kesalahan dalam proses pengeringan; } \\
\text { Panas terlalu tinggi }\end{array}$ & Paska $\mathrm{P}_{2}$ \\
\hline 6 & Biji berwarna pucat & $\begin{array}{l}\text { Pengeringan yang tidak merata/biji yang } \\
\text { sudah kering terkena air }\end{array}$ & Paska p \\
\hline 7 & $\begin{array}{l}\text { Biji berwarna hijau pudar } \\
\text { kekuningan }\end{array}$ & Terlalu lama dalam proses pengeringan, & Paska p \\
\hline 8 & Biji pudar, tua & $\begin{array}{l}\text { Terlalu lama dalam penyimpanan; } \\
\text { Penyimpanan dalam suhu tinggi dan } \\
\text { lembab. }\end{array}$ & Penyim! \\
\hline 9 & $\begin{array}{l}\text { Biji berwarna kuning } \\
\text { pudar, semi-transparan }\end{array}$ & Kekurangan zat besi dalam tanah. & $\begin{array}{l}\text { Perawatan } \\
\text { tanaman }\end{array}$ \\
\hline 10 & Kerusakan serangga & $\begin{array}{l}\text { Serangan serangga sejak dalam masa } \\
\text { buah, atau serangan saat dalam } \\
\text { penyimpanan. }\end{array}$ & $\begin{array}{l}\text { Perawatan } \\
\text { tanaman/penyimp } \\
\text { anan }\end{array}$ \\
\hline 11 & $\begin{array}{l}\text { Biji gepeng } \\
\text { terpotong }\end{array}$ & Biji cacat selama proses pengupasan & Paska panen \\
\hline 12 & Biji basah / tidak kering & Biji tidak dikeringkan dengan sempurna & Paska panen \\
\hline
\end{tabular}

Kerusakan biji kopi yang menempati ranking tertinggi adalah biji kopi yang berwarna hijau pucat dan hampir tidak ada rasa khas kopi. Hal ini disebabkan teknik pemetikan buah kopi yang tidak tepat. Petani seringkali melakukan petik serentak (panen racut) terhadap semua biji kopi baik dalam kondisi sudah merah (matang) maupun masih hijau (mentah). Hal ini mengakibatkan buah kopi yang mentah dikupas atau dikeringkan bersamaan dengan buah kopi yang sudah matang. Biji kopi yang dihasilkan oleh buah kopi yang belum matang memberikan aroma mentah pada saat di seduh. Sebaliknya keberadaan biji kopi berwarna coklat yang dihasilkan dari buah kopi yang terlalu matang atau bahkan mengering di pohon bisa berakibat mengurangi kualitas rasa kopi. 


\section{Sistem Deteksi Kematangan Buah}

Penelitian mengenai deteksi kematangan buah papaya dilakukan oleh (Hermawan, Bettiza, \& Hayaty, 2018). Metode yang dilakukan adalah menggunakan ekstraksi warna HSV. Hasil penelitian menunjukkan sistem mampu melakukan klasifikasi citra dengan baik. Dari 20 kali pengujian buah citra pepaya sistem mampu dengan tepat mendeteksi kematangan 9 buah citra papaya atau dengan kata lain akurasi yang dihasilkan dari sistem adalah 45\%.

Penelitian yang dilakukan oleh (Sulistyo, 2017) mendeteksi tingkat kekuningan daun padi sebagai dasar waktu untuk panen. Metode yang digunakan adalah Fuzzy C-Means Clustering. Sistem dikembangkan dengan Toolbox Graphic User Interface dari MATLAB. Sistem memiliki akurasi penelitian yang baik. Keberhasilan sistem mencapai 94,11\%.

Sedangkan penelitian yang dilakukan oleh (Nasution \& Fadillah, 2019) menentukan kematangan buah tomat berdasarkan warna kulitnya. Buah tomat diklasifikasikan apakah sudah matang, setengah matang, dan mentah. Metode yang digunakan adalah segmentasi warna menggunakan YCbCr. Citra dikonversi dari RGB ke YCbCr. Hasil penelitian didapatkan warna buah tomat yang sudah matang akan berwarna ungu, setengah matang akan berwarna berwarna magenta, dan buah yang masih mentah akan berwarna merah.

Penelitian ini dilakukan dengan menggunakan mini komp Raspberry pi 3 model B

\section{METODOLOGI PENELITIAN}

Alur dari penelitian dijelaskan pada Gambar 1 berikut ini. 


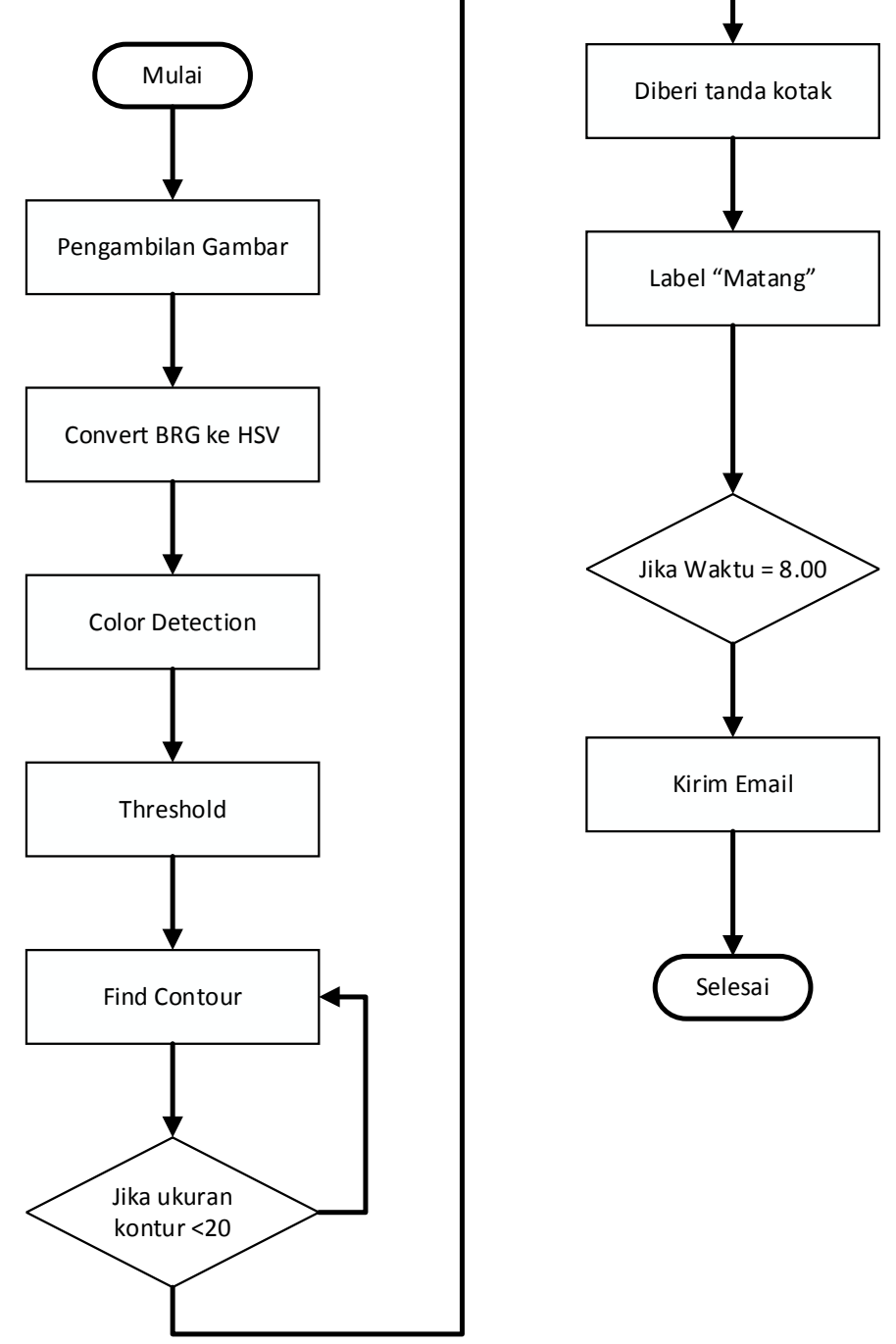

Gambar 1 Alur penelitian

Pengambilan Gambar

Dalam pengambilan gambar ada beberapa kondisi dari proses pengambilan gambar, diantaranya:

Proses pengambilan gambar menggunakan modul kamera Raspberry Pi Camera Board, versi 2 yang dilengkapi dengan lensa Sony IMX219 8MP. Modul kamera kecil ini didesain khusus untuk Raspberry Pi. Kamera memiliki kemampuan untuk menangkap gambar statis 3280 x 2464 piksel. Serta juga mampu menangkap video dengan ukuran hingga1080p 30fps. Dalam proses pengambilan gambar, 
gambar ditangkap dalam format video dan dipisah menjadi masing-masing frame dengan format RGB. Setiap frame akan diproses dengan teknik pengolahan citra digital.

Kamera di pasang menggunakan tripod yang dibuat sejajar dengan pohon kopi. Ketinggian dari permukaan tanah 1,5 meter dengan berbagai jarak pengujian.

Waktu pengambilan gambar dilakukan setiap jam 8 pagi dan jam 4 sore hari. Alasan pengambilan adalah ketika pagi dan sore adalah kondisi cuaca sudah terang sehingga obyek dapat dideteksi. Ketika siang hari sinar matahari akan akan menyebabkan cahaya yang menyilaukan dan obyek menjadi blur. Blur bisa menghalangi proses deteksi obyek buah kopi.

Sudut pengambilan yang bisa di toleransi adalah $15^{\circ}$ derajat. Sudut yang terlalu besar akan menyebabkan distori bentuk obyek yang akan dideteksi.

\section{Pengubahan BRG ke HSV}

Hasil tangkapan citra dari kamera Raspberry Pi 3 disimpan dalam format GRB dan harus diubah kedalam type HSV. HSV merupakan istilah dari Hue, Saturation dan Value. Citra dalam HSV memiliki warna-warna yang sama dengan yang ditangkap oleh indra manusia(Fauzi, Tolle, \& Dewi, 2018). Format citra dalam HSV digunakan dalam metode segmentasi obyek berdasarkan warna. Penelitian yang dilakukan oleh (Sulistyo, 2017)(Muchlis, 2018; Sulistyo, 2017) melakukan konversi RGB to HSV sebagai bagian pre-processing sebelum dilakukan segmentasi obyek.

\section{Deteksi Warna}

Segmentasi merupakan teknik untuk memisahkan area atau region berdasarkan kesamaan atau homogenitas area(Koschan \& Abidi, 2008). Sedangkan segmentasi warna membagi daerah pada citra dengan menganalisis nilai warna dari tiap piksel citra dan membagi gambar sesuai dengan fitur yang diinginkan (Budi Putranto, Hapsari, \& Wsijana, 2011).

Pada penelitian ini bertujuan untuk membedakan kopi yang sudah matang dan belum matang. Kopi yang matang memiliki warna kemerahan hingga merah. Kopi 
yang matang atau mendekati kematangan di definisikan memiliki rentang nilai HSV antara $(0,120,70)$ dan $(22,60,200)$.

\section{Thresholding}

Daerah yang mengandung warna merah selanjutnya akan dipisahkan dengan latar belakang atau backgroundnya. Daerah ini menunjukkan kopi yang sudah matang. Metode yang digunakan adalah metode Thresholding. Thresholding digunakan untuk mengekstraksi atau memisahkan bagian citra berdasarkan nilai intensitas ambang(Tyagi, 2018). Threshold di dahului dengan penentuan nilai ambang. Piksel yang memiliki intensitas lebih besar dari nilai ambang yang ditetapkan, akan memiliki ke nilai tertentu misalkan 1 sedangkan piksel yang lainnya akan bernilai 0 atau sebaliknya. Metode Thresholding yang digunakan adalah metode otsu. Metode otsu merupakan metode yang optimum untuk memaksimalkan varian antar kelas. Kelas yang diberi ambang batas yang benar harus berbeda dengan nilai intensitas pikselnya dan sebaliknya(Gonzalez \& Woods, 2018).

Deteksi Kontur

Kontur merupakan sebuah area yang homogen atau memiliki intensitas yang sama dan terhubung dalam sebuah kurva tertutup. Kontur digunakan sebagai alat untuk mendeteksi dan pengenalan sebuah objek. Kontur didapatkan dengan melakukan deteksi tepi sebuah obyek menggunakan metode thresholding. Setiap kontur yang dideteksi merupakan daerah yang didalamnya terdapat sebuah kopi matang. Kontur yang dideteksi dihubungkan dengan sebuah garis dan diberi tanda kotak dan label matang.

Pengiriman data

Apabila sistem berhasil mendeteksi kopi yang matang, Sistem akan mengurimkan citra melalui email. Modul smtplib digunakan untuk mengirimkan email melalui listener daemon SMTP atau ESMTP.

\section{HASIL DAN PEMBAHASAN}

1. Hasil Penelitian 
Proses penelitian diawali dengan pengambilan citra dari pohon kopi. Dalam sebuah pohon diterdapat kopi yang masih hijau dan sebagian mulai matang. Sebuah citra yang diambil disimpan dalam variabel image, seperti yang ditunjukkan pada Gambar 1.

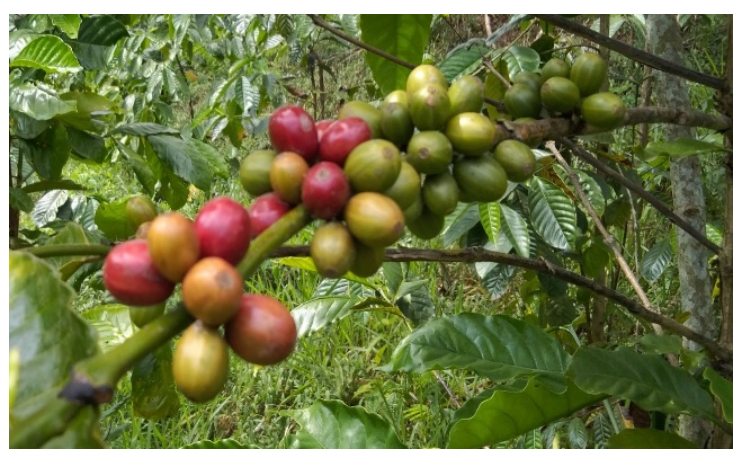

Gambar 1 Obyek sebelum deteksi

Selanjutnya citra diubah kedalam format HSV. Kopi yang masih mentah akan terlihat hijau. Bagian dengan intensitas cahaya tinggi berubah agak kemerahan. Sedangkan kopi yang sudah matang berubah menjadi keunguan setelah diubah kedalam HSV. Citra yang sudah diubah kedalam format HSV ditunjukkan pada gambar 2.

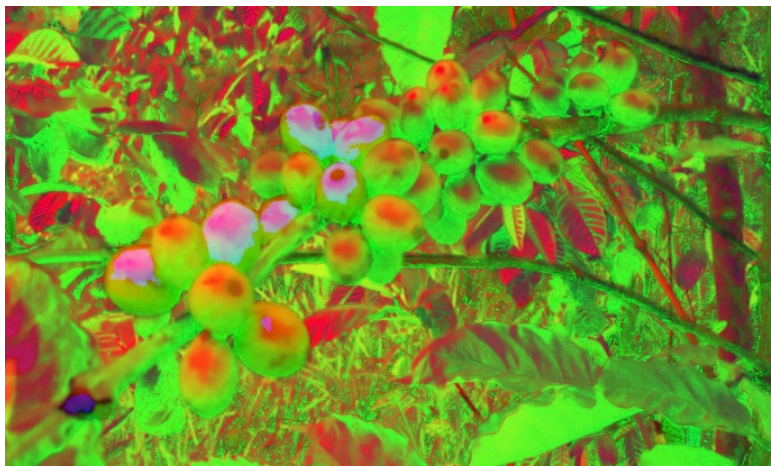

Gambar 2 Hasil pengubahan ke HSV

Setelah pengubahan ke HSV langkah berikutnya adalah Thresholding. Metode ini untuk memisahkan area yang diinginkan dengan latar belakangnya. Area yang mengandung kopi matang akan berubah menjadi hitam sedangkan bagian lain akan diabaikan. Gambar 3 menunjukkan daerah yang mengandung kopi matang. 


\section{$20^{0}$}

Gambar 2

Langkah selanjutnya adalah memeriksa kontur dari area yang mengandung kopi matang. Setiap daerah yang mengandung kopi akan di tandai dengan kotak dan label “matang”. Hasil deteksi kopi matang ditunjukkan pada gambar 5 .

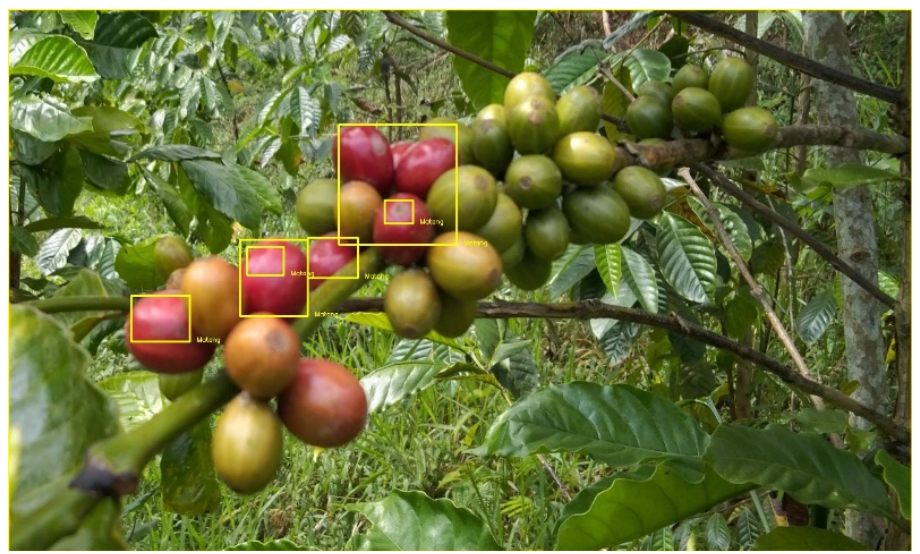

Gambar 3 Hasil deteksi

2. Diskusi

a. Penelitian ini adalah tidak ada pemisahan obyek yang diteliti dengan latar belakang. Alasannya adalah karena Raspberry Pi akan dipasang di kebun kopi. Sehingga tidak memungkingkan untuk memisahkan obyek kopi dengan latar belakangnya. Sebagaimana penelitian yang mengenai deteksi kematangan tomat yang dilakukan oleh (Nasution \& Fadillah, 2019). Akan tetapi beberapa penelitian lain seperti yang dilakukan oleh (Ciputra, Susanto, \& dkk, 2018) dan (Hanafi, Fadillah, \& Insan, 2019) mensyaratkan obyek sudah dipisahkan dari latar belakang. Tidak dipisahkannya obyek dengan latar belakang 
akan mengurangi akurasi dari sistem untuk mendeteksi kopi matang. Obyek lain seperti daun yang kuning, atau obyek yang lain dengan warna kemerahan akan menyebabkan berkurangnya akurasi sistem.

b. Gangguan lain yang yang muncul disebabkan oleh pantulan sinar matahari. Sinar yang terlalu kuat dan arah yang tidak tepat akan menyilaukan dan menyebabkan hasil tangkapan kamera menjadi blur. Blur menyebabkan sistem tidak bisa melakukan deteksi tepi dengan baik sehingga daerah yang mengandung kopi tidak terdeteksi ataupun sebaliknya area yang tidak terdapat kopi matang di deteksi terdapat kopi yang sudah matang.

c. Jarak optimum yang dapat ditangkap dengan modul kamera Raspberry Pi adalah $20-50 \mathrm{~cm}$. Jarak yang terlalu dekat dan terlalu jauh menyebabkan obyek menjadi blur dan tidak dapat diolah dengan metode pengolahan citra digital dengan baik.

d. Buah kopi memiliki karakteristik buah yang kecil dan menggerombol sehingga dalam proses segmentasi dan deteksi tidak memungkinkan untuk memisahkan satu buah kopi dengan buah yang lain. Sehingga dalam proses pelabelan sering terjadi kesalahan kopi yang masih hijau dilabeli kopi yang sudah matang

e. Berbeda dengan obyek lain dalam penelitian kematangan buah apel merah atau jeruk. Proses deteksi kopi matang susah dilanjutkan dengan proses recognition dengan machine learning. Alasannya adalah satu buah kopi tidak bisa dipisahkan dari biji kopi yang lain.

f. Proses notifikasi ke pengguna dengan email bisa dilakukan dengan baik. Sehingga pengguna bisa mendapatkan notifikasi email setiap hari apabila sistem mendeteksi terdapat kopi yang sudah matang.

\section{KESIMPULAN}

Penggunaan kamera yang mengadopsi teknologi Internet Protocol (IP) memudahkan data transfer dilakukan secara simultan dari berbagai lokasi untuk diolah oleh microprocessor secara bersamaan. Dengan penempatan kamera pada berbagai sudut kebun kopi, lokasi buah kopi 
mana yang telah memenuhi syarat untuk dipetik akan bisa disimpulkan oleh aplikasi.

\section{ACKNOWLEDGMENT}

Penelitian ini dilaksanakan dengan dukungan dari dana Hibah PNBP UNS tahun Anggaran 2019.

\section{DAFTAR PUSTAKA}

Budi Putranto, B. Y., Hapsari, W., \& Wijana, K. (2011). Segmentasi Warna Citra Dengan Deteksi Warna Hsv Untuk Mendeteksi Objek. Jurnal Informatika, 6(2). https://doi.org/10.21460/inf.2010.62.81

Ciputra, A., Susanto, A., \& dkk. (2018). Klasifikasi Tingkat Kematangan Buah Apel Manalagi dengan Algoritma Naive Bayes Dan Ekstraksi Fitur Citra Digital. Simetris, 9(1), 465-472.

Fauzi, J. F., Tolle, H., \& Dewi, R. K. (2018). Implementasi Metode RGB To HSV pada Aplikasi Pengenalan Mata Uang Kertas Berbasis Android untuk Tuna Netra. Jurnal Pengembangan Teknologi Informasi Dan Ilmu Komputer, 2(6), 2319-2325.

Gonzalez, R. C., \& Woods, R. E. (2018). Digital image processing. New York, NY: Pearson. https://doi.org/10.1109/MCOM.1981.1090535

Hanafi, M. H., Fadillah, N., \& Insan, A. (2019). Optimasi Algoritma K-Nearest Neighbor untuk Klasifikasi Tingkat Kematangan Buah Alpukat Berdasarkan Warna. IT Journal Research and Development (ITJRD), 4(1), 10-18. https://doi.org/10.25299/itjrd.2019.vol4(1).2477

Hermawan, B., Bettiza, M., \& Hayaty, N. (2018). Menentukan tingkat kematangan buah pepaya dengan ekstraksi warna. Universitas Maritim Raja Ali Haji.

Koschan, A., \& Abidi, M. (2008). Digital Color Image Processing. New Jersey: Wiley Interscience Publication.

Muchlis, N. F. (2018). Deteksi kemerahan pada kulit wajah dengan teknik pengolahan citra. Universitas Islam Indonesia.

Nasution, M. S., \& Fadillah, N. (2019). Deteksi Kematangan Berdasarkan Warna Buah dengan Menggunakan Metode YCbCr. InfoTekJar:Jurnal Nasional Informatika Dan Teknologi Jaringan, 3(2), 147-150.

Sulistyo, I. A. (2017). Sistem Deteksi Panen Padi Berdasarkan Warna Daun Menggunakan Fuzzy C-Means. Tugas Akhir Universitas Muhamadiyah Surakarta. Universitas Muhamadiyah Surakarta.

Tyagi, V. (2018). Understanding Digital Image Processing. Florida: Taylor \& Francis Group, LLC.

ICO. (2019). National Quality Standard. In: International Coffee Organization. 